\title{
A comprehensive evaluation of the effectiveness of a day patient treatment program for eating disorders
}

\author{
Lara Winten ${ }^{1 *}$, Stephanie Quinton ${ }^{1}$, Suzanne Abraham², Janice Russell², Georgina Luscombe ${ }^{2}$ \\ From 2014 ANZAED Conference: Driven Bodies Driven Brains \\ Fremantle, Australia. 22-23 August 2014
}

Day patient (DP) programs represent a significant development in the treatment of eating disorders, however currently there is a dearth of literature evaluating the effectiveness of DP treatment based upon the targeted goals of treatment. This study aimed to explore the effectiveness and short-term stability of an Australian DP program by examining change across the seven key goals of treatment using a naturalistic pre-post-follow-up study design. The sample included 75 participants meeting criteria for an eating disorder who were admitted to the Northside Clinic DP program. Participants completed measures assessing eating disordered cognitions, readiness to change, quality of life, perpetuating factors, co-morbid factors, body mass index (BMI), and eating disordered behaviours. Fifty-eight patients completed the DP program and 17 dropped-out of treatment. The results demonstrated that there were significant improvements between admission and discharge across all seven targeted areas of treatment, which were maintained at follow-up. Identified predictors of program completion included independent living and attendance travel time of one hour or less. The only identified predictor of good outcome was higher BMI at admission. The results are discussed in the context of other published studies, and potential directions for future research are suggested.

This abstract was presented in the Service Initiatives stream of the 2014 ANZAED Conference.

\section{Authors' details}

${ }^{1}$ Charles Sturt University, Bathurst, Australia. ${ }^{2}$ University of Sydney, Sydney, Australia.

\footnotetext{
* Correspondence: larawintenpsychology@gmail.com

${ }^{1}$ Charles Sturt University, Bathurst, Australia

Full list of author information is available at the end of the article
}

Published: 24 November 2014

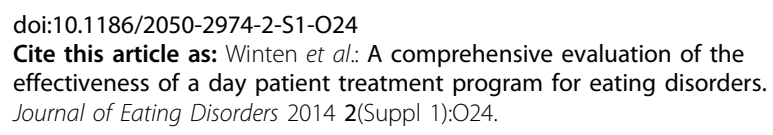

Cite this article as: Winten et al:: A comprehensive evaluation of the effectiveness of a day patient treatment program for eating disorders. Journal of Eating Disorders 2014 2(Suppl 1):O24.

Submit your next manuscript to BioMed Central and take full advantage of:

- Convenient online submission

- Thorough peer review

- No space constraints or color figure charges

- Immediate publication on acceptance

- Inclusion in PubMed, CAS, Scopus and Google Scholar

- Research which is freely available for redistribution

Submit your manuscript at www.biomedcentral.com/submit
( Biomed Central 